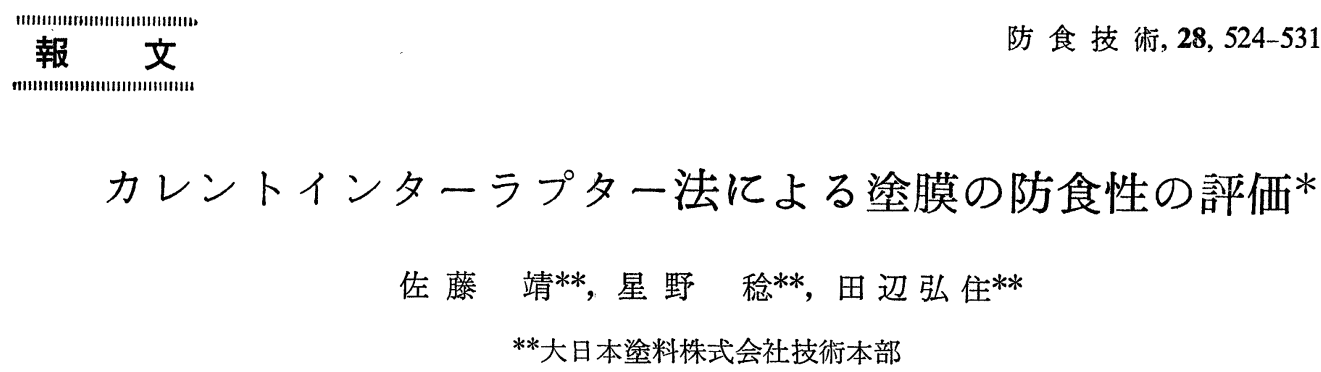

\title{
Application of Currentinterrupter Method to the Estimation of Protective Coatings*
}

\author{
Yasushi Sato**, Minoru Hoshino** and Hiroyuki Tanabe** \\ **Research and Development Department, Dai Nippon Toryo Co. Ltd.
}

\begin{abstract}
The corrosion rate of coated mild steel was investigated using the technique of current interrupter method. Generally the high impedance of film had been a barrier to measure the corrosion rate of coated mild steel but this method made it easy to eliminate the impedance of film and furthermore to obtain the polarization behavior of coated mild steel. The equivalent circuit of coated mild steel immersed in a $3 \mathrm{wt} \%$ sodium chloride solution is composed of two kinds of impedance circuit, that is, the impedance circuit of paint film and that of metal interface beneath paint film. These circuits were easily separated because of the large difference of time constants between the one circuit and another. Therefore the polarization resistance was obtained under the condition of small polarization (up to $10 \mathrm{mV}$ ) and Tafel's coefficient was given by the relation between time and potential in decay curve of small polarization to the extent of $200 \mathrm{mV}$ to $300 \mathrm{mV}$. And the corrosion rate of coated mild steel was calculated using Stern's equation. This method is characterised by items below. (I) Very small current was applied to paint film for a few seconds so that no damage appeared throughout measuring. (II) The impedance of film and that of metal surface under paint film were measured simultaneously. As a result, the corrosion rate of coated mild steel coincided with the appearance of underfilm corrosion throughout immersion tests.
\end{abstract}

\section{1. 緒}

過去に执いて，叙装鋼板の腐食の測定は主に外観観察 によっていたが，近年これを電気化学的に取り扱打うと する試みがなされてきた。たとえば，塗装鋼板のインピ 一ダンスを測定する方法1),2), 3)，塗膜カット部を対象に 電気化学的に測定する方法 ${ }^{4)}$, 塗膜抵抗を補正すること により分極曲線を測定する方法 ${ }^{5)}$ な゙゙が塗膜下の腐食研 究に用いられている。これらの方法はそれぞれ対象とす る現象が異なっている。本研究は塗膜下の腐食反応をカ レントインタラプター法を応用することにより測定する ことを目的としている。

塗膜下の應食反応を電気化学的に取り扱う際の最大の 障害は塗膜のもつ高抵抗であり，いかにその抵抗を除去 乙, 下地金属界面の電気化学的応答を的確に把握するか が焦点となる。これらの塗装鋼板の分極曲線を測定し塗

* 淮膜下腐食の研究 (第 1 報) (Studies on Underfilm Corrosion (Part 1))

** T230 横浜市鶴見区大東町 12-1, (12-1, Daitocho, Tsurumi-ku, Yokohama 230, Japan)
膜下の腐食速度を検討する場合，比較的長時間塗膜に高 電圧が印加されることになり，塗膜損傷のおそれるあ る。最近カレントインタラプター法に似た方法で, 電極 界面への影響が活とんぞなく腐食速度が測定できるクー ロノスタット法早,7)が適用されているが，高抵抗塗膜塗 装鋼板への適用はこれまでに報告されていない。

本研究ではカレントインタラプター法を適用すること により, 塗膜インピーダンスの測定, およびその塗膜イ ンピーダンスを分離除去することにより塗膜下の腐食速 度の測定を試みた。すなわち，一般に塗装鋼板の等価回 路として, 溶液の純抵抗, 塗膜の容量㧍よび抵抗, 塗膜 下金属界面の容量（二重層容量）および抵抗がそれぞれ 直列回路を形成していると考えられる。

そこで塗膜の時定数と下地鋼板の時定数が著しく異な る場合には，等価回路の構成成分である塗膜の分極，下 地鋼板の分極，溶液の純抵抗は分離が可能になる。この 点を利用して, 食塩水溶液中に打ける塗装鋼板の分極特 性を測定し，これによって塗装鋼板の腐食速度を求める ことにより，溆膜下腐食の検討を行った。 


\section{2. 実験方法}

\section{1. 供試料および測定セル}

測定に使用したセルを図 1 に示す。エメリーペーパー でNo. 600 まで研磨した軟鋼板 (JIS G 3141) を, キシ レンで脱脂し, 乾燥の後, 塗装をほどこしたものを試料 電極とした。これにパッキングをはさんでガラスセルを 装着し, 測定電極面積を $12.6 \mathrm{~cm}^{2}$ とした。このガラス セルは白金対極, 飽和甘录電極を挿入する目的から, 摺 り合わせになって拈り，完全密閉にすることも可能であ る。試料試験片の浸漬液は $3 \mathrm{wt} \%$ 食塩水溶液とした。

\section{2 測定回路}

測定セルを含めた測定回路を図 2 に示した。定電流発 生装置 (C.P.G) の精度は約 $10^{-9} \mathrm{~A}$ である。この定電流 発生装置に測定電極セルを接続する。このセルに定電流 を印加した際の電位応答を, インピーダンス変換器 (北 斗電工 HE 102）を介して記録計に検出する。インピー ダンス変換器の性能から, 定格の $10^{14}$ 程度の入力インピ 一ダンス，すなわち塗膜のインピーダンスまで測定が可 能である。塗膜下の金属の分極現象のように，分極現象 が比較的遅い場合には, 記録計を使用することによりこ の分極現象の検出は充分可能であった。これに対し, 塗 膜の分極現象のように, 分極現象が速い場合は, オッシ ロスコープで検出した。

\section{3 測定方法}

カレントインターラプター法8) とは, 定電流電解にお ける電流の印加, 切断時の分極過渡現象の観測に基づく ものである。たとえば塗装鋼板をその適用の対象とする ことができる。塗装鋼板の等価回路を簡略化して図 3 に 示した。ここで $R$ は純抵抗で, この場合溶液抵抗がこれ に相当する。塗膜に相当するインピーダンスが $C_{f}, R_{f}$ で表わされ，金属界面のインピーダンス $C_{d l} ， R_{e}$ と直 列回路を形成しているとして, その結果時定数に顕著 な差異が存在すれば，それぞれの分極現象を分離する ことが可能になる。一般には溶液抵抗は数十オーム以下 であり,また塗膜回路では容量が約 $10^{-8} \sim 10^{-10} \mathrm{~F}$, 抵
抗が約 $10^{6} \sim 10^{7} \Omega$ であるから，時定数は容量と抵抗の 積の関係から約 $1 \mathrm{~m} \mathrm{sec}$ 程度となる。金属界面のインピ 一ダンスは容量が約 $10^{-5} F$, 分極抵抗が約 $10^{6} \Omega$ 程度

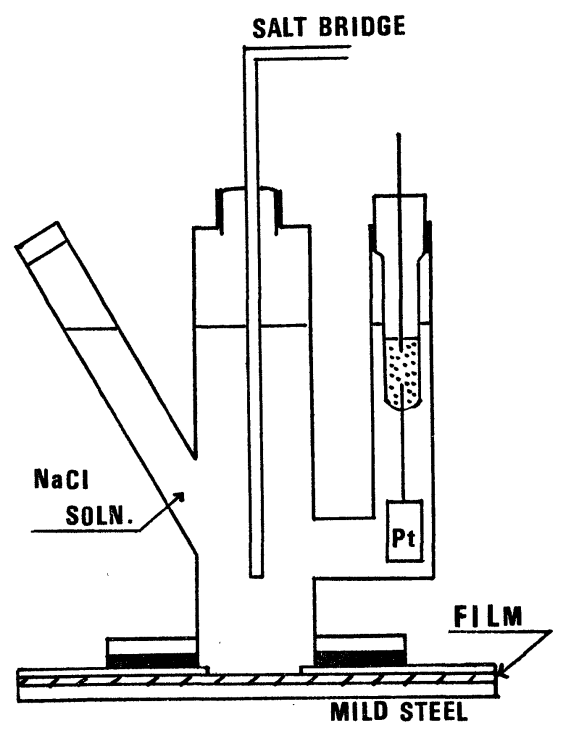

Fig. 1 Schematic diagram of the cell for the electrochemical measurement.

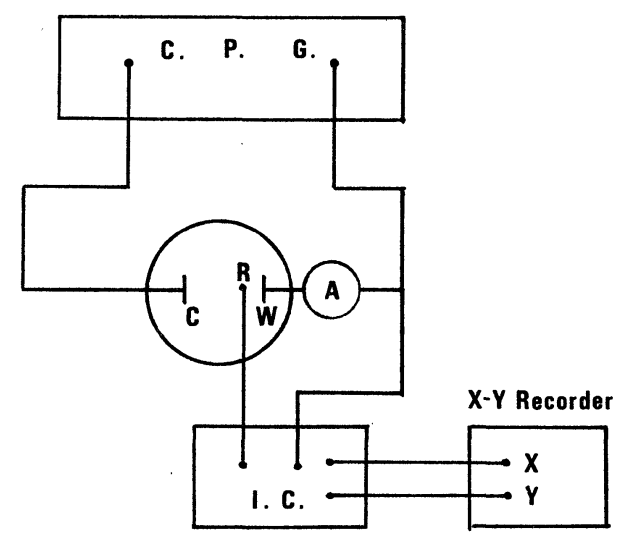

Fig. 2 Circuit of measuring underfilm corrosion.

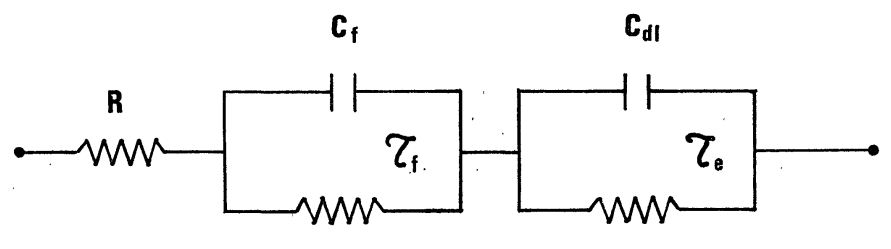

$\mathbf{R}_{\mathbf{f}}$

$\mathbf{R}_{\mathbf{e}}$

$$
\begin{array}{lllll}
\mathbf{C}_{\mathrm{f}} & 10^{-9} & \mathrm{~F} / \mathrm{cm}^{2} & \mathbf{C}_{\mathrm{d} 1} & 10^{-5} \mathrm{~F} / \mathrm{cm}^{2} \\
\mathbf{R}_{\mathrm{f}} & 10^{6} & \mathrm{ohm} \cdot \mathrm{cm}^{2} & \mathbf{R}_{\mathrm{\theta}} & 10^{6} \mathrm{ohm} \cdot \mathrm{cm}^{2} \\
\tau_{\mathrm{f}} & 1 & \mathrm{msec} & \tau_{\theta} & 10 \mathrm{sec}
\end{array}
$$

Fig. 3 Equivalent circuit of coated mild steel. 


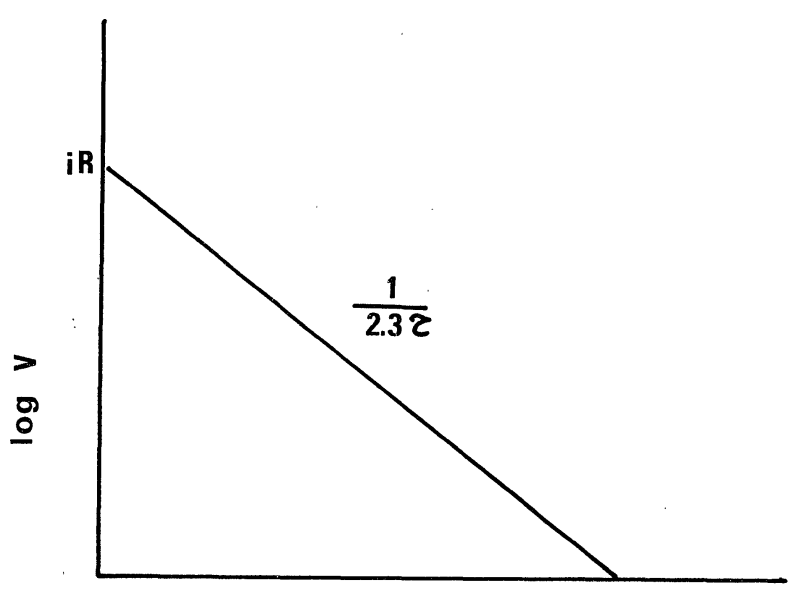

t ime

Fig. 4 Relation between potential and time であるとすれば，時定数は約 $10 \mathrm{sec}$ 程度となる。塗膜 の時定数が $1 \mathrm{~m} \mathrm{sec}$ であるのに対し, 金属界面の時定数 は $10 \mathrm{sec}$ であり，これらの間には顕著な差がみられ， その結果，両者を分離して和の扮のを検討することがで きる。過去に扚いて Rozenfeld ら`涂膜鋼板のオーミ ック抵抗と分極抵抗を分離し検討を試みたが，塗膜下金 属界面の分極抵抗を論じたものはほとんどない。

\subsection{1 塗膜の分極}

図 3 のよらに塗膜のインピーダンスを単一の $C, R$ 素子 で示すと, 定電流印加の際の分極現象は次式であらわさ れる。

$$
i=i_{R}+i_{c}=V / R+C(d v / d t)
$$

従って

$$
V=i R\left(1-e^{-t / \tau}\right) \quad(\tau=C R)
$$

また電流切断時の電位減衰は

$$
V=i R e^{-t / \tau}
$$

従って

$$
\log V=\log i R-t / 2.3 \tau
$$

となる。これをグラフで表わせば図 4 となり，これから 時定数 $\tau$ と容量 $C$, 抵抗 $R$ を求めることができる。

\subsection{2 金属界面の分極}

塗膜下金属の素地面では，定電流印加時に浸漬液を介 して電極反応，すすなわら腐食反応が括こる。いま $O_{x}+$ $n e \rightleftarrows R_{e d}$. なる酸化還元系の電極反応の電位と電流の関 係は, 電極表面上の反応種の濃度が, 沖合濃度と平衡に なっている時, ファラデー電流 $i_{f}$ は

$$
i_{f}=i_{0}[\exp (-\alpha n F \eta / R T)-\exp \{(1-\alpha) n F \eta / R T\}]
$$

であらわされる。ここで

$i_{0}$ : 交換電流密度

$\alpha$ : 遷移係数

$n$ : 反応電子数

$F:$ ファラデー定数

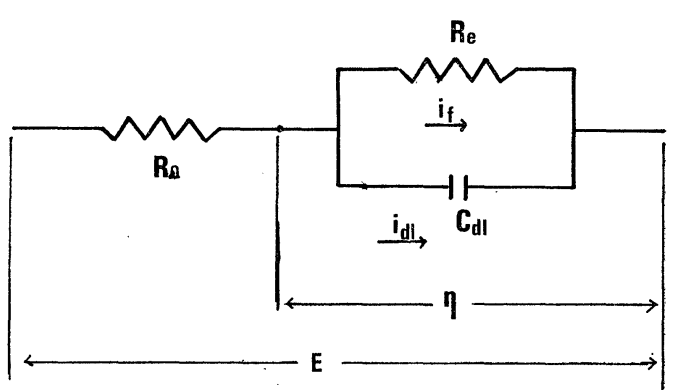

$R_{e}$ : polarization resistance

$R_{\Omega}$ : resistance of solution

$C_{d l}$ : double layer capacitance

$i_{f}$ : Faradaic current

$i_{d l}$ : double layer charging current

Fig. 5 Equivalent circuit of oxidation and reduction system

\section{$R$ : 気体定数 \\ $T:$ 絶対温度 \\ $\eta$ : 過電圧}

ただし式 (3) は電解開始直後とか, 電子移動反応抵抗 がきわめて大きい場合に適用できるもので, 一般には電 解が進むにつれて, 電極界面に反応種の濃度勾配ができ るので電流と電位の関係は

$$
\begin{aligned}
i_{f}= & i_{0}\left[\left(C_{0} / C_{0}{ }^{*}\right) \exp (-\alpha n F \eta / R T)\right. \\
& \left.-\left(C_{R} / C_{R}{ }^{*}\right) \exp \{(1-\alpha) n F \eta / R T\}\right]
\end{aligned}
$$

であらわされる。ここで $C_{o}, C_{R}$ は電極面上の $O_{x}$ およ び $R_{e d}$. の濃度である。本研究に括いては, 低電流密度 を短時間印加することにより, 電極界面の反応種の濃度 勾配の発生を極力除去したこと, また式の単純化をはか り，その取り扱いを容易にする意図から，式（3）をもっ て論じることにした。

この電極系を電気的に等価な回路に和き換えると図 5 のようになる。この場合の反応抵抗 $R_{e}$ は反応速度に反 比例し, 塗膜下での低腐食反応速度の場合の腐食電流密 度 $i_{\text {corr. }}$ を $10^{-8} \mathrm{~A}$ とすると $R_{e}$ は約 $10^{6} \Omega$ 程度とな る。また $\mathrm{C}_{d l}$ は通常 $10^{-5} \mathrm{~F}$ 程度である。これから時定 数は $10 \mathrm{sec}$ 程度となって, 塗膜の時定数との差が大き いため，明瞭に分離できることになる。

定電流印加の際

$$
\begin{array}{r}
i=C_{d l}(d \eta / d t)+i_{0}[\exp (\alpha n F \eta / R T) \\
-\exp \{(1-\alpha) n F \eta / R T\}]
\end{array}
$$

i) $\quad n F \eta / R T \ll 1$ のとき $(\eta \leqq 10 \mathrm{mV})$

式 (5) の指数関数を展開して近似すると, $0<\alpha<1$ で あるから

$i=C_{d l}(d \eta / d t)+i_{0}[(1+\alpha n F \eta / R T)-\{1-(1-\alpha) n F / R T\}]$

$=C_{d l}(d \eta / d t)+i_{0} n F \eta / R T$

(6) の微分方程式を解いて

$$
\eta=\left(i / i_{0}\right)(R T / n F)\{1-\exp (-t / \tau)\}
$$




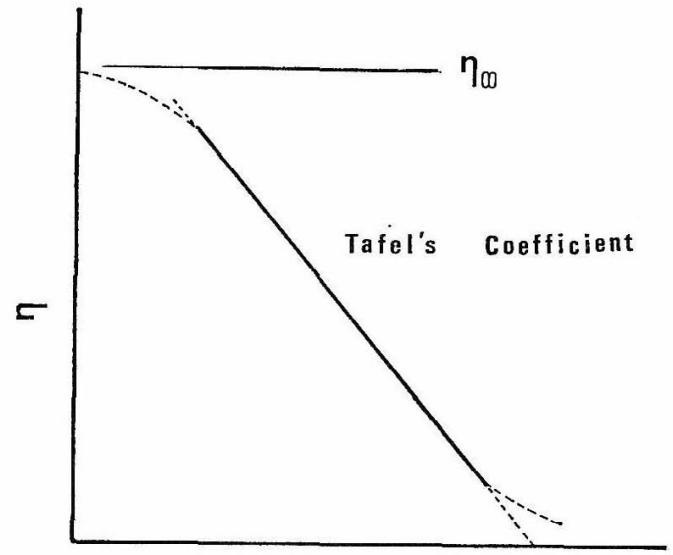

\section{log time}

Fig. 6 Relation between potential and time (decay curve).

$$
\text { ここに } \quad \begin{array}{ll}
\tau=C_{a l} R T / n F i_{0}=C R_{e} \\
& R_{e}=R T / n F i_{0} \\
& i_{0}=R T / R_{e} n F \\
& C_{d l}=\tau / R_{e}
\end{array}
$$

$t$ が非常に小さい場合は $i_{d t}$ に比して $i_{f}$ は無視でき るので

$$
i=C_{d l}[d \eta / d t]_{t=0}
$$

また式 (7) は式 (2) と全く同様に取扱らことができる ので図 4 のグラフから $\tau, R_{e}, C_{d t}$ が求まり $R T / n F$ が 既知であれば $i_{0}$ すなわら腐食速度も求まる。

ii) $n F \eta / R T \gg 1$ のとさ

アノード分極の場合はカソード電流が無視できるので

$$
i=C_{d l}(d \eta / d t)+i_{0} \exp (\alpha n F \eta / R T)
$$

電流切断の際の減衰時は $i_{d l}=-i_{f}, i=0$ と打るので

$$
C_{d l}\left(d_{\eta} / d t\right)=-i_{0} \exp (\alpha n F \eta / R T)
$$

この微分方程式を解くと

$$
t=\left(C R T / i_{0} \alpha n F\right) \exp (-\alpha n F \eta / R T)
$$

従って

$\eta=(-R T / \alpha n F) \ln t+(R T / \alpha n F) \ln \left(C R T / i_{0} \alpha n F\right)$

となり，図 6 の $n-\log t$ の関係から，ターフェル係数 が求まる。

得られたターフェル係数と分極抵抗 $R_{e}$ とから，スタ ーソの式 (17) より腐食速度が求をる。

$$
i_{\text {corr. }}=b_{a} \cdot b_{c} / 2.3 R_{e}\left(b_{a}+b_{c}\right)
$$

ただし式 (16) は $\eta<10 \mathrm{mV}$ の範囩で成立する。

$$
\text { ここに } \quad \begin{aligned}
& b_{a}=2.3 R T / \alpha n F \\
& b_{c}=2.3 R T /(1-\alpha) n F
\end{aligned}
$$

\section{3. 実験結果および考察}

\section{1 塗膜の分極}

前記の実験方法に從い，艺の塗装鋼板電極に微少定電

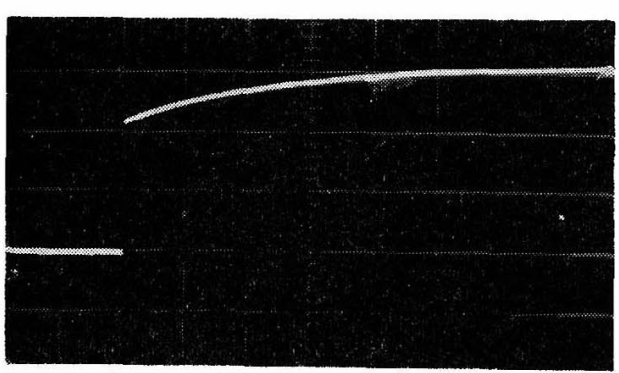

A $1 \mathrm{sec} /$ div. $100 \mathrm{mV} /$ div.

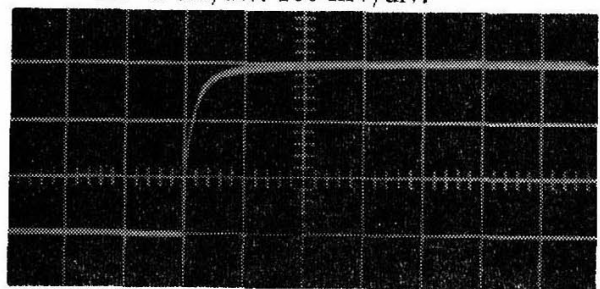

B $5 \mathrm{msec} /$ div. $100 \mathrm{mV} / \mathrm{div}$.

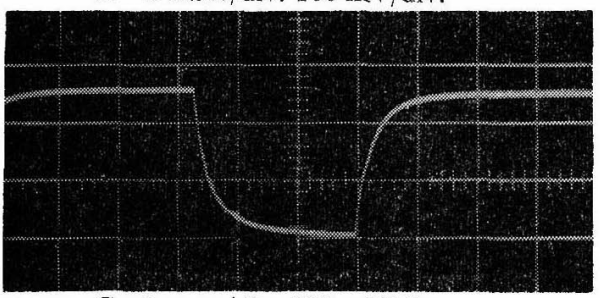

C $2 \mathrm{msec} /$ div. $100 \mathrm{mV} /$ div.

Fig. 7 Polarization of coated film. Applied current $0.5 \mu \mathrm{A}$ (oscilloscope).

流を印加して，その電位变化をオッシッスニープにより 観測した（図 7, A, B , C)。塗装鋼板としては，アクリル エマルション塗料を $35 \mu \mathrm{m}$ 塗装したるのを使用した。 これを $3 \mathrm{wt} \%$ 塩化ナトリウム水溶液中に浸漬して測定 に供した。図7A は塗装鋼板電極に0.5 $\mu$ A を印加した 時の過渡現象，それに続く電位経時変化を示している。 この図のオッシロスコープによる測完の条件は, 横軸掃 引速度 $1 \mathrm{sec} /$ 月盛, たて軸電位変化 $100 \mathrm{mV} /$ 目盛であ る。電流印加苜後に電位の急激な上昇が少られ，それに 続いて比較的勾配の緩慢な曲線を得た。前者は塗膜の分 極による応答，後者は金属一塗膜界面の分極抵抗に基す く応答である。

ここでこの過渡現象を解析する目的で, オッシロスコ 一プの掃引速度を短時間に設定して，その応答を観測し た。図 7B は掃引速度 $5 \mathrm{~m} \mathrm{sec} /$ 目盛, 図 7C $2 \mathrm{~m} \mathrm{sec} /$ 目盛 の場合の観測図である。叙膜の分極に関する解析方法を 次にのベる。図 7 の電位の急上昇部分は,塗膜の分極によ るものであることはすでに記した。印加電流值を用いる ことで,この急な電位変化の值から塗膜抵抗を求めるこ とができる。またこの急激な電位変化の值は塗膜分極の 場合の飽和分極值として近似できる。このことは図 7B, Cの掃引桩大図からも明らかである。ここに図 $7 \mathrm{Cより}$ 
Table 1 Resistance, capacitance, and time constant of coated mild steel

\begin{tabular}{llll}
\hline \hline Polarization & $R_{f}(\mathrm{ohm})$ & $C_{f}(\mathrm{pF})$ & $\Im_{f}$ (msec) \\
\hline Anode $0.5 \mu \mathrm{A}$ & $4.0 \times 10^{5}$ & 1500 & 0.6 \\
Cathode $0.5 \mu \mathrm{A}$ & $4.8 \times 10^{5}$ & 1667 & 0.8 \\
A.C. $\quad 1 \mathrm{KHz}$ & $6.5 \times 10^{5}$ & 1580 & 1.03 \\
\hline
\end{tabular}

In $3 \mathrm{wt} \% \mathrm{NaCI}$ solution at room temperature

$\tau$ が得られる。従って， $\tau$ は $C$ と $R$ の積で得られるこ とから, 塗膜容量 $C$ も求めることができる。

これとは別に, 図 4 の電位減衰時の時間の対数と電位 の関係からも $\tau$ 护よび $C$ を求めることができる。

以上の方法に従い, 試料電極に対し, アノード方向, カソード方向に定電流を印加した際の分極過渡現象より 求めた塗膜の抵抗, 容量, 時定数を表 1 亿示した。測定 值の比較を容易にするため, 印加電流を $0.5 \mu \mathrm{A}$ と一定 にした。比較の意味で, 同一試験片の $1 \mathrm{~K} \mathrm{~Hz}$ の場合の 交流インピーダンスを求めた。アノード方向に電流印加 すると, 塗膜抵抗は $4.0 \times 10^{5} \Omega$, 容量は $1500 \mathrm{PF}$ であ

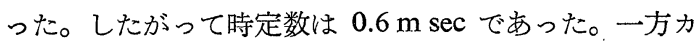
ソード方向では, 塗膜抵抗は $4.8 \times 10^{5} \Omega$, 容量は 1667

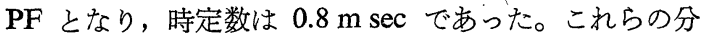
極の結果はきわめてよく一致した。同一塗膜を対象に,

$1 \mathrm{~K} \mathrm{~Hz}, 200 \mathrm{mV}$ の印加条件で交流インピーダンスを測 定すると, 抵抗 $6.5 \times 10^{5} \Omega$, 容量 $1580 \mathrm{PF}$, 時定数 1.03 $\mathrm{m} \mathrm{sec}$ であった。これは前述の結果ときわめてよく一致 した。アクリルエマルシション塗膜は，一般の溶液型塗料 に比較して耐水性が劣るものであり, 上記抵抗, 容量, 時定数の測定值はほ淁妥当であると思われる。

\section{2 塗膜下金属界面における分極}

微少定電流印加時の初期過渡現象が塗膜の分極に起因 することはすでに述べた通りであるが，この現象の後に 続く分極現象は下地金属界面によるものである。一般に 分極抵抗法の適用範囲は $10 \mathrm{mV}$ 以内の小分極の場合之 されている。そこで塗装鋼板の場合についても，その範 囲内で成立するか否かを調べた。（表 2 ）供試料は膜厚 $35 \mu \mathrm{m}$ のアクリルェマルジョン塗装鋼板である。印加電 流は $2.5 \times 10^{-3} \mu \mathrm{A}, 7.0 \times 10^{-3} \mu \mathrm{A}, 11.5 \times 10^{-3} \mu \mathrm{A}, 13 \times$ $10^{-3} \mu \mathrm{A}$ ，とした。その時の分極はそれぞれ $3 \mathrm{mV}, 9 \mathrm{mV}$ ， $13 \mathrm{mV}, 18 \mathrm{mV}$ であった。分極が增大すれば，分極抵抗 も僅かに增大する傾向が認められたが，その差異は小さ く，問題にする程のものではないと考㝋られる。また， 塗膜抵抗を求めたところ, それぞれ $6.8 \times 10^{5} \Omega, 8.6 \times$ $10^{5} \Omega, 9.2 \times 10^{5} \Omega$ であった。これらの值はほ湆同一と みなすことができる。

以上の結果から，少なくとも分極が $10 \mathrm{mV}$ 以下の範 囲では分極抵抗值は等しいといえる。したがって, 塗装
Table 2 Relation between polarization potential and $\operatorname{Re}$

\begin{tabular}{cllll}
\hline $\begin{array}{c}\text { Polarization } \\
(\mathrm{mV})\end{array}$ & $\begin{array}{l}\text { Applied cur- } \\
\text { rent }(\mu \mathrm{A})\end{array}$ & Re (ohm) & $R_{f}$ (ohm) \\
\hline 3 & $2.5 \times 10^{-3}$ & $1.20 \times 10^{6}$ & $6.8 \times 10^{5}$ \\
9 & $7.0 \times 10^{-3}$ & $1.29 \times 10^{6}$ & $8.6 \times 10^{5}$ \\
13 & $11.5 \times 10^{-3}$ & $1.30 \times 10^{6}$ & $9.2 \times 10^{5}$ \\
18 & $13.0 \times 10^{-3}$ & $1.38 \times 10^{6}$ & $8.3 \times 10^{5}$ \\
\hline
\end{tabular}

In $3 \mathrm{wt} \% \mathrm{NaCl}$ solution at room temperature

鋼板の場合にも， $10 \mathrm{mV}$ 以下の範囲で印加電流と分極と の関係に和ける直線性が得られ，その結果，分極抵抗法 が適用できることがわかった。

\section{3 ターフェル係数}

一般にターフェル係数は式 (17)，(18）であらわされ る。鉄の腐食反応が電荷移動過程により支配される場合 には,ターフェル係数はアノード域で約 $60 \mathrm{mV}$, カソー ド域で約 $120 \mathrm{mV}$ とされている。

ところで中性環境下では，その腐食反応は物質移動過 程により支配されることが多い。カソード反応の酸素還 元反応に抢ける拡散支配はこの例である。この場合，正 確には，電荷移動過程に依存するターフェル係数值の適 用は困難であると思われるが，あえて検討を試みた。

塗装鋼板の与える自然電極電位を中心に，約 $200 \mathrm{mV}$ 程度カソードまたはアノード方向に分極後, 印加電流切 断時の減衰曲線より，式 (15) 飞従い，時間の対数之電 位の関係をプロットし，その直線部分の勾配から，ター フェル係数を求めた。カソード分極時に打けるターフェ ル係数は約 $220 \mathrm{mV}$ から約 $50 \mathrm{mV}$ にわたり分散した。 その一例を図 8 に示した。図 9 はアノード分極時の一例 を示したが，この場合もカソード分極の場合と同様，タ ーフェル係数は約 $200 \mathrm{mV}$ と約 $50 \mathrm{mV}$ の間に分散し た。

塗膜下鋼板の腐食反応に扩けるターフェル係数は，非

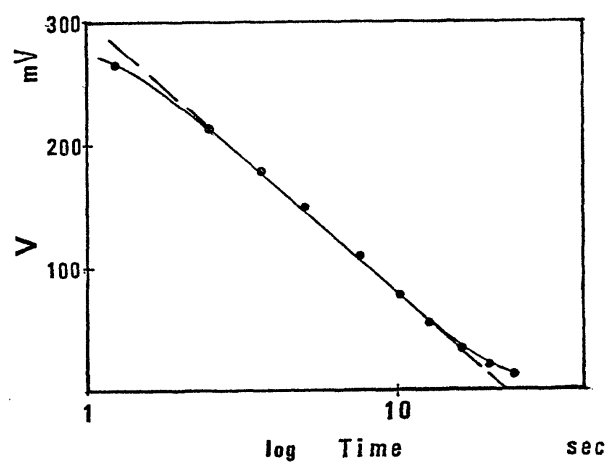

Fig. 8 Relation between potential and time in decay curve (cathode). Acryl emulsion coating $30 \mu \mathrm{m}$. 


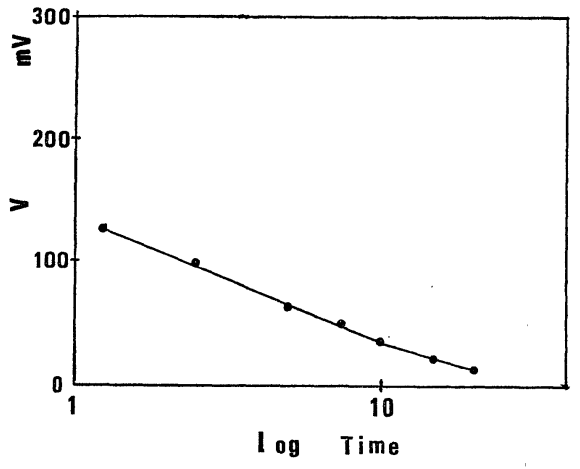

Fig. 9 Relation between potential and time in decay curve (anode) Acryl emulsion coating $30 \mu \mathrm{m}$.

Table 3 Coated mild steel sample.

\begin{tabular}{lccc}
\hline $\begin{array}{l}\text { Thermosetting acryl } \\
\text { coatings }\end{array}$ & \multicolumn{2}{c}{$\begin{array}{l}\text { iNon-thermosetting acryl } \\
\text { emulsion coatings }\end{array}$} \\
\hline Sample & $\begin{array}{c}\text { Thickness } \\
(\mu \mathrm{m})\end{array}$ & Sample & $\begin{array}{c}\text { Thickness } \\
(\mu \mathrm{m})\end{array}$ \\
\hline A & 27. & D & 35 \\
B & 10.5 & E & 22 \\
C & 9.5 & F & 14 \\
\hline
\end{tabular}

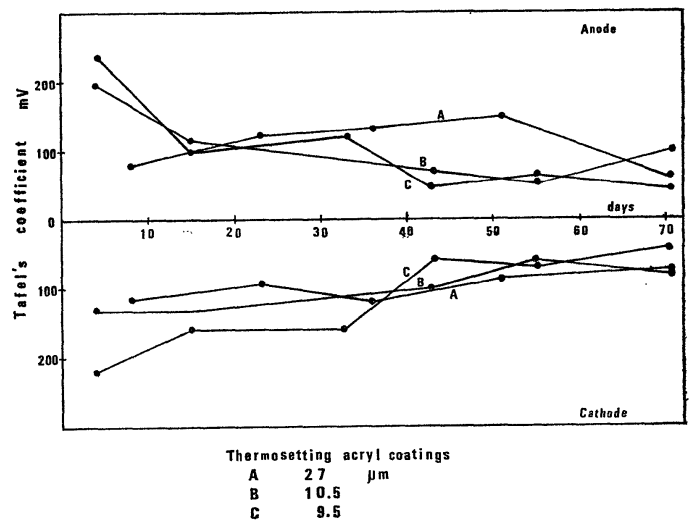

Fig. 10 Time variation of Tafel's coefficient of coated mild steel. $3 \mathrm{wt} \% \mathrm{NaCl}$ solution at room temperature.

塗装鋼板のそれとかなり異なる值を与える結果となり， さらに検討すべき点を多く含んでいるが，これらの測定 值を用いて，式（16）から腐食電流を求めることを以下 と試みた。

\section{4 塗膜下鋼板の腐食電流}

$3 \mathrm{wt} \%$ 塩化ナトリウム水溶液中に浸漬した塗装鋼板の 腐食電流を，3.2, 3.3 で得た分極抵抗，ターフェル係数 を用いて, 式 (16) より求めた。対象塗膜を表 3 亿示し た。

各種塗装鋼板の腐食電流経時変化を求めた際のターフ

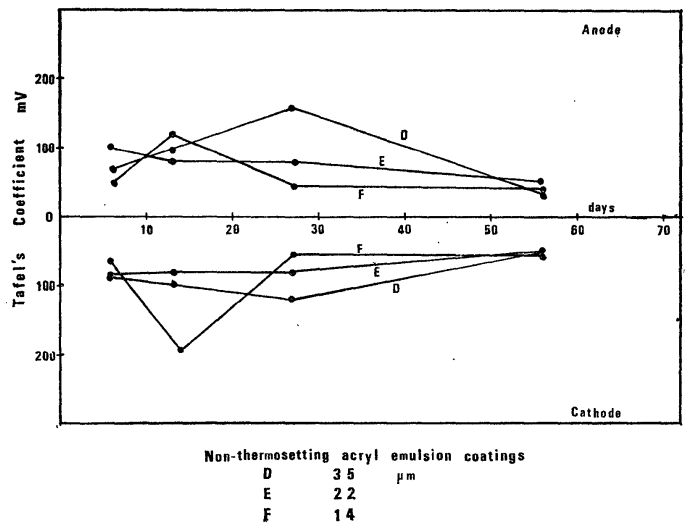

Fig. 11 Time variation of Tafel's coefficient of coated mild steel. $3 \mathrm{wt} \% \mathrm{NaCl}$ solution at room temperature.

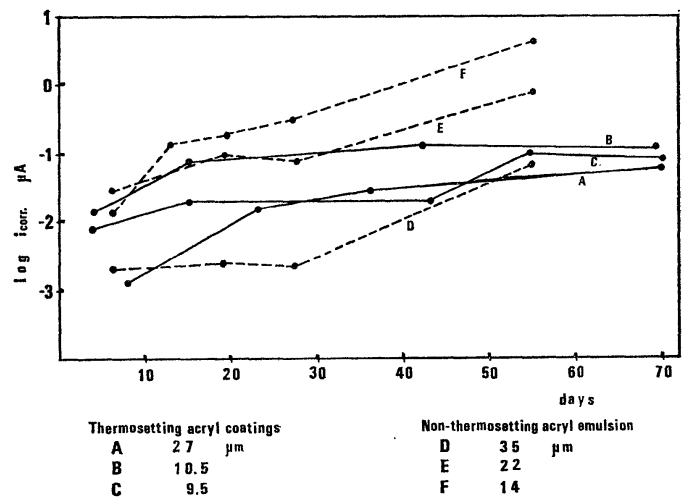

Fig. 12 Relation between corrosion rate of coated mild steel and immersion time. $3 \mathrm{wt} \%$ $\mathrm{NaCl}$ solution at room temperature.

ェル係数を，熱硬化型アクリル塗装鋼板については図10 に，常温乾燥型アクリルェマルジョン塗装鋼板について は図 11 に示した。たて軸にターフェル係数をアアノー ド，カソードについてとり，横軸に試験片の塩化ナトリ ウム水溶液中での浸漬日数を示した。アノード，カソー ド分極域のいずれの場合も, 浸漬初期に拈いてターフェ ル係数は比較的大きい值であったが，浸漬時間の経過と 共に減少の傾向が認められた。また膜厚の差による著し い影響は認められなかった。すなわち試料間の差はある るが，それらがそのまま膜厚差によるものとは説明でき ない。また同一試料，同一条件のもとで，アノード，カ ソード両域に括ける值を検討した結果, 極性, 膜厚の影 響を明らかにすることは困難であった。これらターフェ ル係数の与える意味については明らかでなく，検討を要 するが，以下ではこれらの值をそのまま用いて，塗膜下 での腐食電流值を求めた。腐食電流值は, 塗装鋼板を $10 \mathrm{mV}$ 以下に分極して得られる分極抵抗值と，前記のタ ーフェル係数とを用い，式(16)より得られる。 
塗膜厚敊よび塗料の種類による塗膜下腐食電流への影 響を検討することを目的として，熱硬化型アクリル塗 膜, 常温乾燥型アクリルェマルジョン塗膜を使用した。 図 12 はこれらの塗膜下腐食電流の浸漬経時変化を示し た。熱硬化型アクリル塗膜, 常温乾燥型アクリルェマル ジョン塗膜のいずれも, 膜厚の増大とともに腐食電流值 は減少した。熱硬化型アクリル塗膜は浸漬初期には腐食 電流は抑制され, 10 日を経過するころからやや增大傾向 にあるが, 20 日経過後は汇ぼ定常状態になり 70 日以後 もこれらの腐食電流は $10^{-7} \mathrm{~A}$ 以下であつた。一方常温 乾燥型アクリルエマルジョン湮膜では浸漬初期の腐食電 流值は比較的低く抑制されていたが，浸漬時間の経過と 共に著しく増大した。これは熱硬化型アクリル塗膜の場 合と異なり, 腐食電流值は 50 日浸漬後に $10^{-6} \mathrm{~A}$ 程度 に達するものもあった。

外観観察に抢ける発錆の程度と塗膜下腐食電流の関係 を検討した(図 13)。上記アクリル塗膜で, 膜厚が $10 \mu \mathrm{m}$ から $50 \mu \mathrm{m}$ 程度の範囲にある塗膜を対象にして, 浸漬 の過程に和ける発錆を観察した。すなわち浸漬中の発錆 の認められない状態から追跡を開始し, 肉眼で認められ る程度の発錆があらわれ，その数が増加する過程々腐食 電流值との関係を求めた。錆の認められない状態ではい ずれの場合も $10^{-2} \mu \mathrm{A}$ 以下の腐食電流值であった。発錆 が認められた試料では, その点錆数の増加と共に, 腐食 電流は広範に増加する傾向にあったが, まれであるが $10^{-2} \mu \mathrm{A}$ 以下で，すでに錆を有するものもあった。一度 発錆が認められたものについては, その点錆数に直接関 係なくかなり広範なばらつきがあった。これは錆の数,

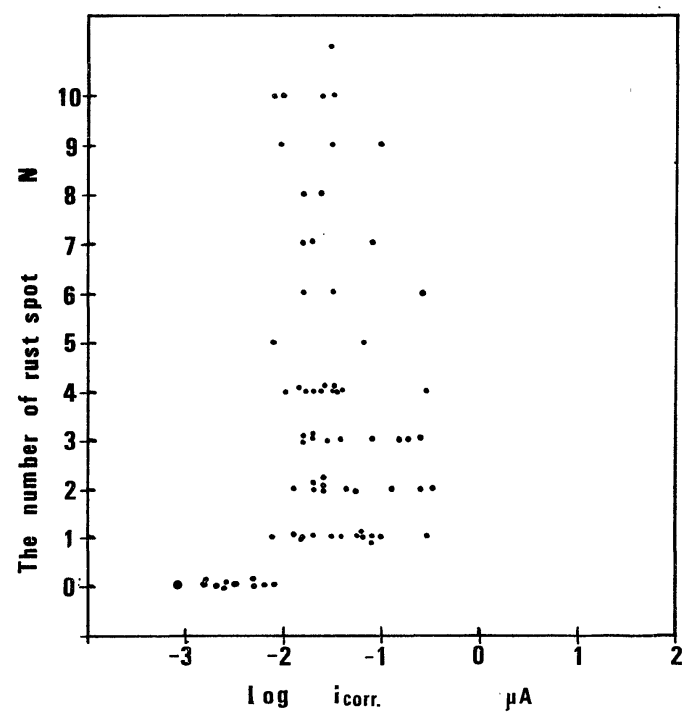

Fig. 13 Relation between corrosion rate and the rate number of corrosion. $3 \mathrm{wt} \%$ $\mathrm{NaCl}$ solution at room temperature.
大きさ, 腐食面積, 錆の種類を考慮しなければならない。 つぎに塗膜下腐食電流值と塗膜抵抗，分極抵抗の関係 を検討した。図 14 に塗膜下の腐食電流值と塗膜抵抗と の関係を示した。測定值にかなりのばらつきがあるがお お゙むね直線関係にあった。すでに明らかにしたように， 発錆の認められない試料の腐食電流值は約 $10^{-2} \mu \mathrm{A}$ 以下 であった。これを塗膜抵抗值から検討すると, 発錆の認 められない試料では $5.5 \times 10^{6} \Omega$ 以上であった。すなわ ち腐食電流值が $10^{-2} \mu \mathrm{A}$ 以下, 塗膜抵抗が $5.5 \times 10^{6} \Omega$ 以上の条件を満たす試料については, 全く発錆は認めら れなかった。例数が少なく, 限られた塗膜からの結論で あるために，断定はできないが，興味ある事実である。

図 15 に腐食電流と分極抵抗の関係を示した。測定值

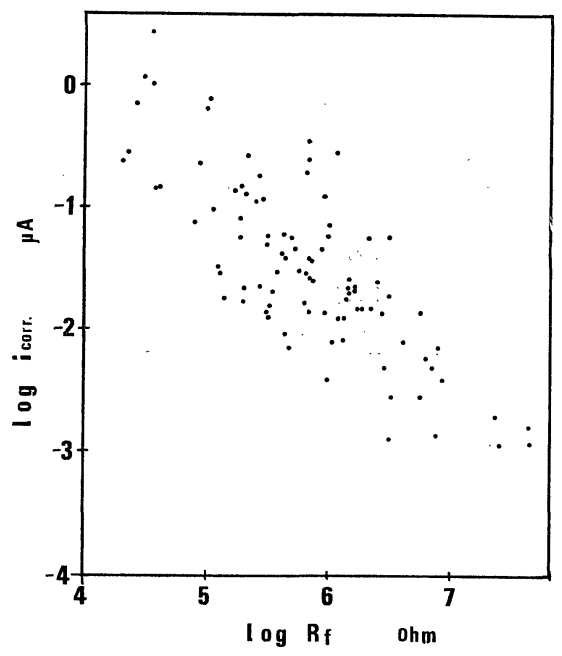

Fig. 14 Relation between corrosion rate and resistance of coated mild steel.

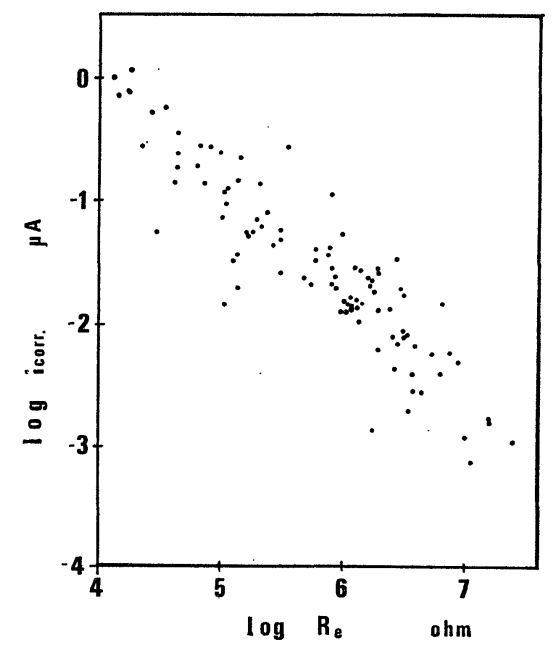

Fig. 15 Relation between corrosion rate and polarization resistance of coated mild steel. $3 \mathrm{wt} \% \mathrm{NaCl}$ solution at room temperature. 
の分散傾向が多少認められたが，ほぼ直線関係にあっ た。すなわち図 15 の結果はー1 の勾配をもつ直線とな った。式 (16) に扎いて, ターフェル係数 $\beta_{a} \cdot \beta_{c}$ が一定 であるという仮定をおくと, 腐食電流值の対数と分極抵 抗値の対数の関係は -1 の勾配をもつ直線になり, 先の 実験值と一致した。したがって本研究に和ける実験に用 いた測定方法はほぼ妥当であると思われる。

\section{3. 結 論}

カレントイソターラプター法により塗装鋼板の腐食電 流の測定を抢こなった。本研究では微少定電流を塗装鋼 板に印加し, その際の電位応答を塗膜分極と塗膜下金属 界面の分極とに分離することができた。アクリル塗料塗 装鋼板について，この塗膜下金属界面の分極抵抗を測定 し, 腐食電流值を求めた。各係数のらち, 分極抵抗はほ ぼ妥当な值を得た。ターフェル係数は, いわゆる鋼板の それとはかなり異なる值を与え，比較的大きい值になっ た。これについてはさらに今後検討する必要がある。

得られた腐食電流值で $10^{-2} \mu \mathrm{A}$ 以下，塗膜抵抗 $5.5 \times$ $10^{6}$ 以上の試料については発錆が認められず, この範囲 外のものに発錆が認められた。すなわら塗膜劣化と腐食 電流との間の相関性が求められた。
カレントインターラプター法による塗膜下腐食測定の 特色は, 測定に際し, 塗膜に微少定電流を短時間印加す るにすぎず，塗膜損傷を含め悪影響を与えることなく， 塗膜下の腐食電流が測定できることと，塗膜抵抗と塗膜 下金属界面の分極抵抗を同時に測定できることにある。

本研究ではカレントインターラプター法の塗膜下腐食 への適用の可能性を明らかにしたが，今後さらに個々の 現象を詳細に検討し，ぬたより高抵抗を有する塗膜に応 用してゆく予定である。 (Received April 2, 1979)

\section{文 献}

1) 岡本 剛, 諸住 高: 電気化学, 23, 15 (1955).

2) 岡本 剛, 諸住 高: 電気化学, 24, 259 (1956)

3) 佐藤 靖: 電気化学, 26, 646 (1958)

4) H.F. Clay: J. Oil Col. Chem. Assoc., 52 158 (1969).

5）山本 隆, 尼子 宏, 大藪権昭：色材, 48, 352 (1975)

6) P. Delahay: J. Phys. Chem., 66, 2204 (1962)

7) K. Kanno, M. Suzuki, Y. Sato: J. Electro chem. Soc., 125, 9, 1389 (1978).

8) J. O'M Bockris, E. C. Potter: J. Electrochem. Soc., 99, 169 (1952).

9) I. L. Rosenfeld: Lakokrasoch. Mater. Primen. No. 6, 45 (1964). 